\title{
Mainstreaming English Language Learners: Does It Promote or Hinder Literacy Development?
}

\author{
Esther Somé-Guiébré \\ ${ }^{1}$ College of Education, University of Koudougou, Burkina Faso \\ Correspondence: Esther Somé-Guiébré, College of Education, University of Koudougou, Burkina Faso, BP 34 \\ Saaba 01, Burkina Faso. E-mail: somee.uk@gmail.com
}

Received: October 19, 2015 Accepted: December 1, 2015 Online Published: December 3, 2015

doi:10.5539/elt.v9n1p33

URL: http://dx.doi.org/10.5539/elt.v9n1p33

\begin{abstract}
This study examines the interaction between African immigrant students and their mainstream teachers. I am particularly interested in the influence of classroom practices on the literacy development of Francophone African immigrant children in the U.S. classroom. The student participants in this study (two French speaking African students) were all permanent residents in the United States. They were all born and schooled in their home countries and were fluent in French (the language of instruction in their home countries). Since their immigration to the U.S. with their parents, the children have been confronted to several linguistic, social, cultural, and economic challenges that slowed down their academic progress and achievement. This paper uses Krashen's (2005) discussion on language acquisition to argue that specific classroom practices can hinder the literacy development of immigrant children. The data used for this discussion was collected through the observation of a $5^{\text {th }}$ grade classroom, informal conversations with two French speaking African students and interviews with their mainstream teacher as well as their English as a Second Language (ESL) teachers.
\end{abstract}

Keywords: literacy development, English language learners, French speaking, African immigrants

\section{Introduction}

The issues regarding English language learners in the United States have received some significant attention in the literature of the academic achievement of immigrant children. However, much of that literature examines the case of children from Hispanic and Asian background while children from African background have remained to a large extent invisible. The growing number of African immigrant children in the U.S. classrooms entails a need to highlight their linguistic, social, and cultural challenges in the classroom.

This paper examines the extent to which classroom practices promote or hinder the literacy development of two immigrant students from French speaking African countries. The argument is that classroom practices often hinder literacy development as mainstream American teachers are scarcely prepared to teach English language learners (ELLs) (Nieto, 2002) which makes it difficult to adjust instruction and make it accessible to their immigrant students (Harklau, 1994).

The student participants for this study (two $5^{\text {th }}$ graders) were fluent in the French language that was used as a language of instruction in their home countries, and Lingala their mother tongue. One of them had only moved to the U.S. five months prior to data collection and was still struggling to socialize in English. The second one, however, was starting her third year of schooling in the United States and spoke English fluently. However, she was yet to develop the academic language which according to Verplaetse and Migliacci (2008) takes about 5 to 10 years. The study then explored their classroom activities with the expectation of unravelling the difficulties faced by immigrant students in developing literacy in English as a second language.

\subsection{Theoretical Framework}

This study uses Krashen's (2005) discussion about second language acquisition. Krashen makes a distinction between language acquisition and language learning and argues that language acquisition occurs when acquired in a naturalistic environment while language learning implies gaining knowledge of the new language through a formal, classroom-type environment. He notes that the best way to teach a language to second language learners is through comprehensible input, and views interaction as a rich source of input for L2 learners. Crawford (2005) also puts a strong emphasis on communicative learning with a focus on content rather than on grammar. Through 
such an approach, oral errors are not directly corrected. Communication and comprehension are viewed as the focus of reading and writing and teachers develop strategies promoting them. Barrera (1983) also makes a similar observation and argues that English language learners learn English by reading in context. She calls teachers' attention to the fact that children's oral and written language is able to develop simultaneously and support each other.

Barrera (1983) argues that reading is acquired in context through comprehension and is not conditioned by the level of oral fluency. She urges teachers to devote less time to pronunciation as it de-motivates L2 learners.

Reading comprehension was also discussed by Garcia (2003) who advocates for the use of content knowledge to teach ELLs. She argues that content knowledge exposure allows them to develop "the necessary vocabulary and linguistic structures relevant to the domain." (p. 43).

Another discussion about second language literacy development is related to the role of students' first language literacy level. Purcell-Gates (2002) emphasizes that:

"If you are forbidden to use your language to learn to read and write, if you are forced to speak differently when reading and writing, then you are in effect being closed off, or at least seriously impeded from accessing the world of print" (p. 134).

First language literacy could be very important in second language learning through students' awareness of cognates between French and English. Wallace (2008) defines cognates as "vocabulary items in two different languages that are similar both orthographically and semantically" (p. 190). In his argument, ELLs could take advantage of the existence of cognate pairs to transfer a large number of words from their first language to English. Templeton (2009) also uses cognates to discuss meaning relationships among different languages and argues that "as students read, talk about, and explore cognates, they are learning much more than the meanings of particular words in a new language; they are learning processes of thinking about language in general and the discourses, large and small that scaffold meaning systems in the new language" (p. 200). Similarly, Cummins (2000) points out that linguistic knowledge can be transferred from one language to another when they share the roman orthography. He notes that "the linguistic and literacy knowledge and skills that an individual has learned in his or her L1 [first language] will be brought to bear on the learning of academic knowledge and skills in L2 [second language]" (p. 190). It is important that teachers become aware of their students' level of literacy in their first language as well as their cultural background for an effective development of literacy in the second language.

Another point discussed in the literature is related the preparation of teachers to be culturally and linguistically sensitive. It entails an exposure to culturally inclusive pedagogies and knowledge of second language acquisition (Goodwin, 2002; Lucas et al., 2008; Nieto, 2002; Verplaetse \& Migliacci, 2008). Lucas et al. (2008) write that, "to be successful with ELLs, however, teachers need to draw on established principles of second language learning" (p. 362). They explain the necessity for teachers to acquire a body of knowledge on language acquisition through a connection between language and content. According to them:

"To succeed in U.S. schools, students must be able to read academic texts in different subject areas, produce written documents in a language appropriate for school, and understand their teachers and peers, all in English. Therefore, language cannot be separated from what is taught and learned in school." (p. 362)

Goodwin (2002) further views second language instruction as a significant component of teacher education and underlines that "part of teacher preparation will have to be the content and methods of second language instruction as well as strategies for creating a language-rich-classroom environment and developing cooperative and community based learning" (p. 168). Teachers should not only teach curriculum content to immigrant children, they should also assist their students in their transition to American cultural and linguistic values.

\subsection{Research Questions}

1) What are the linguistic and academic challenges of African immigrants?

2) How do classroom practices influence literacy development?

\section{Methodology}

This was a naturalistic study using descriptive data and participants' perspectives (Bogdan \& Biklen, 2007). Throughout the study, I conducted daily classroom observations in order to understand the nature of the challenges Francophone African immigrant students faced in the development of their literacy skills in English. The study allowed me to understand the actions observed in their natural setting. 


\subsection{Study Site and Participants}

The data were collected in a Midwestern elementary school with a student population that was dominantly Caucasian. The student population also comprised Blacks, Asians, Hispanics, and Native Americans. The black population included 10 students who were mostly natives of French speaking African countries. The study involved two $5^{\text {th }}$ graders originating from French Speaking African countries and had received at least three years of formal schooling in French in their home countries. They both reported that their parents mostly spoke to them in French and in Lingala. Both participants were girls, and were pseudo-named Rita and Nadine. They were both pulled out of their mainstream classrooms for ESL classes. Rita, who had just immigrated (5 months prior to data collection), was pulled out twice a day for 40 minutes. As for Nadine, she was only pulled out once a day for 40 minutes because the school administration decided she had acquired enough academic and linguistic skills to spend as much time in ESL classroom. She had been schooled in the U.S. for three years. Besides, at the end of the school year, Rita's teacher recommended that she repeats the $5^{\text {th }}$ grade because her academic performance was low. I followed up with Rita the following year, when she is referred to as Rita 2.

Four teachers were involved in the research: Mrs. Banks, the $5^{\text {th }}$ grade teacher (I refer to her as Mrs. Banks2 as she works with Rita2 the following academic year), Mrs. Li, and Mrs. Clark both English as second language (ESL) teachers. Mrs. Banks had been teaching for three years at the time of data collection. Throughout the three years, she taught students of diverse backgrounds. However, my student participants were her first exposure to African students. As for Mrs. Clarks, she travelled a lot throughout her childhood and lived in Europe and Asia. She worked as a classroom teacher for several years, before moving to Japan where she taught English for a year. Her stay in Japan motivated her interest in ESL teaching. She then took college level courses for an ESL endorsement. Last but not least, Ms. Li had only been teaching ESL two years.

\subsection{Data Sources}

The data for this study was collected through observation field-notes, audio-tapes, and interviews. I observed Rita and Nadine's classroom three days a week for three month from 8.30 am to $2.00 \mathrm{pm}$ both in their mainstream and ESL classrooms. As for Rita2, I observed her mainstream classroom twice a week for two months for a couple of hours. Observing classroom discussions allowed me to immerse in the lives of my participants in order to have a deeper grasp of their experiences and their perspectives (Emerson, Fretz, \& Shaw, 1995). I audio-taped the discussions between Rita2 and her teacher and later transcribed them. This was instrumental in understanding the interactions between the two parties. The last method of data collection was semi-structured interviews involving the teachers (Mrs. Banks, Mrs. Banks2, Mrs. Li, and Mrs. Clark). I also had informal conversations with Rita, Nadine, and Rita2. The interviews deepened my understanding of the events and activities observed and helped me make sense of the findings from the perspective of the participants.

\subsection{Data Analysis}

I used inductive procedures to analyze the data. The analysis was based on the data collected through the observation sessions, the interviews, and informal conversations. I used thematic units of analysis which consisted of a cross-case analysis of the interviews "by grouping together answers from different people to common questions or analyzing different perspectives on central issues" (Patton, 1990, p.376). It also involved the organization of the observation data around key issues and/or themes. The thematic units of analysis were supported by "communicative acts" that occurred during classroom interactions (Dyson \& Geneshi, 2005, p. 87). My decision to pay close attention to the communicative acts was based on Mehan's (1992) view of social interaction as a tool for learning.

\section{Findings}

The findings in this paper are discussed in accordance with the following themes: Content knowledge exposure, collaboration between ESL and mainstream teachers, and interaction between teachers and English language learners as presented below

\subsection{Content Knowledge Exposure}

My observation showed that the participants received very limited exposure to content knowledge. Although they were all in mainstream classrooms, they did not always have the same level of exposure as students fluent in English. For instance, Rita was taken away from the classroom twice a day for 40 minutes per session. Most of the time, she left the classroom in the middle of a subject and got back in the middle of another. According to Mrs. Banks, Rita did not participate in math because she [Mrs. Banks] did not know her level in math. For instance, she noted that "Rita is turning in her work on time; she is trying hard to understand." Mrs. Banks however added that she was really "taking it easy with her [Rita] this year" because the school had a 
conversation with her parents about keeping her back in fifth grade for the following school year. She noted that:

"I think the ... she [Rita] is coming along with the reading. But her math is lacking and as an ESL teacher I could focus on. But my job is to focus on English. If we had more time... She is coming along in reading and with more one-on-one meetings, she would progress very quickly. But math, I am not sure. What saddens me is the sciences and social studies. She might be getting a little bit in her class, but I am not sure. I am not sure what she is doing even there. I do wish that there was a way that she could be doing like a $1^{\text {st }}$ grade type of social studies without putting her in a $1^{\text {st }}$ grade classroom. But that's really what she needs, to put the language with what she is doing."

Low exposure to content knowledge was also true for Rita2. Although she was more fluent in English, she was still very passive during classroom activities. The most common activities for her were reading and writing. She made a lot of progress in her writing compared to Rita. Rita2 had a wider range of vocabulary words but was still struggling with spelling. Her spelling errors included grammatical mistakes such as "I gived my dad money." Her grammatical mistakes, however, did not prevent the reader from understanding the message portrayed. According to Krashen (2005), a focus on grammar slows down language acquisition. A successful language learning program lays emphasis on the communicative purpose of language learning. In her writings, she used situations that were familiar to her personal experiences to learn how to write. The use of situations familiar to her home settings not only motivated her but also facilitated her literacy development. Similar to Purcell-Gates' (2002) argument that preventing students from using their first language impedes literacy development, encouraging the use of familiar settings in writing assignments motivated Rita2 and enhanced her learning process.

Rita2 was also pulled out twice a day but once for ESL and the second time for tutoring either in reading or in mathematics. Tutoring often took place whenever the tutor was available and according to the needs of the teacher. For instance, during a math class, Mrs. Banks2 (Mrs. Banks in the second year) divided the class in three groups which she taught in turns. While the other two groups worked on math assignments with volunteer tutors. She once asked Ms. Nancy (a school volunteer) to work on multiplication of decimals with her group that included Rita2. As soon as Ms. Nancy started her math session, Rita2's ESL teacher walked in and Rita2 had to go for ESL. Rita2 was often away in the ESL class during mathematic classes.

Nadine on the other hand received more exposure to content knowledge because her more advanced language abilities allowed her to spend more time in the mainstream classroom. She only left her class once a day for ESL at 1:30 p.m. Besides being in the classroom for most of the day, her ESL curriculum focused more on content knowledge. According to her ESL teacher, "her class modifies the science and social studies units to make it more accessible to them [the students]." For instance, during one of her classroom sessions, Mrs. Li's ESL class discussed "meteorites." Mrs. Li first had the students take turns reading about rocks in a text. Then, the teacher asked them to answer the comprehension questions on the next pages. The lesson continued with the following discussion on adverbs.

Mrs. Li (asked her students): what are adverbs.

Nadine: they give more details.

Mrs. Li: ok. They modify.

She then gave them a sheet of paper with a list of adverbs and incomplete sentences on it. She told them that they were expected to fill in each blank with the correct adverb.

Mrs. Li analyzes Nadine's work as follows

"Spelling can be too difficult for her [Nadine]. She didn't understand short and long vowel sounds and that made it difficult for her. The nice thing is that she's had a reading group that is at her level. Science and social studies are ok because they are hands on. The teacher has more time to break things down to her level. Math I guess is really difficult because we just don't have enough teacher time to help."

\subsection{Lack of Collaboration between ESL Teachers and Mainstream Teachers}

Another hindrance to the literacy development of my student participants was the lack of collaboration between both mainstream and ESL teachers about what is taught and when it should be taught. As I noted in the methodology, the children were pulled out of their mainstream classroom once or twice a day for ESL depending on their linguistic abilities. The pull out often took place in the middle of a lesson and they often came back in the middle of another lesson. That was often a hurdle for the students as they were evaluated on the same ground as the rest of the class. According to Mrs. Li (Nadine's ESL teacher), Nadine's ESL content knowledge 
curriculum is was supposed to prepare Nadine for what is taught in class. However, there was never any instance where she and Mrs. Banks discussed its implementation. As a result, Nadine was often exposed to a given topic in the mainstream class a month or two before the topic was discussed in the ESL classroom. Mrs. Clark, Rita2's ESL teacher made a similar comment about the lack of coordination of the topics being taught and attributed it to a lack of time.

\subsection{Limited Interaction between Teachers and Their English Language Learners}

Another striking finding is the limited interaction between the mainstream teacher and the English language learners. The interaction was often conditioned by the level of fluency of the students. The higher their fluency, the more interaction there was with the teacher. For instance, Mrs. Banks once asked the class to write down stories that she read and discussed with them. When she read Nadine's story, she underlined the misspelled words, asked her the meaning of sentences that she did not understand, and engaged in a discussion about what was discussed in the paper. She did the same for all the students in the class. But when it was Rita's turn, she read it quietly and did not do any correction, did not ask any question, and gave it back to her saying "very nice!"

The writing assignment was an opportunity for Mrs. Banks and Nadine to converse. The teacher read the assignment and demonstrated her interest in it through the establishment of a two-way conversation between her and her student. In the case of Rita, however, the conversation did not take place. Although Mrs. Banks encouraged Rita through her statement "very nice," she also implied a lack of interest in her writing by not engaging her in any form of conversation. Such an approach revealed the discrimination against Rita that could frustrate and disempower her (McDonald \& Smolen 1995).

Another example of the lack of interaction was a reading activity given to Rita. She was assigned to go on the computer and listen to stories. For one hour she read stories such as "Little Red Bat" and "Animals Are Sleeping." Eventually, she stopped reading, talked to Nadine in Lingala who then asked Mrs. Banks if Rita could go back to her seat because she had listened to all the books. Mrs. Banks responded "humm! I guess so." Nadine then reported the answer to Rita, who went back to her seat.

The reading activity given to Rita was not guided. She was simply expected to read and be busy. Not being given any specific guidance about the reading made the activity isolated and purposeless. Crawford (2005) discussed guided reading activities as conducive to communication. A communicative approach to reading comprehension would allow students to answer and ask questions about the text and then support the students' journey towards literacy development (Iddings et al., 2009). The activity given to Rita, however seemed to have one and only one purpose: keep her occupied. The lack of guided activity unraveled once more the low expectation Mrs. Banks had of Rita, given her linguistic abilities in English.

\subsection{The Role of the First Language and Home Environment in Second Language Acquisition}

The immigrant students' first language and/or native language was always welcome in the classroom. It was very common to hear Nadine and Rita discuss in the classroom at the request of Mrs. Banks. Nadine often served as a translator for Mrs. Banks and the conversations between the two girls often took place either in French or in Lingala but most often in Lingala. Although Rita was often dependent on her peer to communicate with her teacher, she participated in classroom activities relying on similarities between French and English. During a spelling activity held during one of my observations, the teacher dictated 17 spelling words, each followed by its meaning. Here are some of Rita's spellings:

'expedijen' instead of 'expedition'

'capten' instead of 'captain'

'pediture' instead of ' pedicure'

'decapeted' instead of ' decapitate'

'captivide' instead of 'captivity'.

Although she misspelled all the words, she wrote all the sounds she heard. Her knowledge of the letter sound in French might have been significant in her spelling word (Ladson-Billings, 2007).

Besides the first and native language, the home culture was also often welcome in the classroom and was most of the time present during their writing assignment. Below is one of Rita2's writing assignments

Family

"My mom like to go to the school and my dad like to read the book anytime and go to school too with my mom 
read the book my sister come and look my mom said what you need I need food and my mom said this is not food if you when to eat food go ask your sister my reading my book and my dad ask my brother just go read your book okay."

A reading of this story demonstrates that Rita2 was able to communicate in English. Although she made several grammatical errors and lacked general punctuation such as full stops, commas, capitalization, her message is comprehensible to a large extent. The reader is able to follow her thoughts, although it is difficult at times because of the lack of punctuation. Rita2's use of the language exemplifies Krashen's (2005) discussion of language acquisition versus language learning. Although she was learning the language for academic purposes, she was still at the communicative language level. Her academic language was far from being achieved.

Another important point raised in Rita's writing is the significance of education for her family. As the writing reveals, reading was an important practice for literacy development. Rita's parents read at home mostly for their own survival in the U.S. as they were taking English classes at the local community college. They set the right example for their daughter by creating a reading culture at home. As a matter of fact, Villas-Boas (1998) argues that when parents read at home, they expose their children to reading practices that affect their literacy development positively.

\section{Discussion}

Krashen (2005) discussed comprehensible input as the best way to teach a language. He argues that neither repetitive drill nor grammar approaches are effective ways of teaching language. Interaction with language, however, provides a significant source of input. Unfortunately, as I discussed in the findings, the interaction between the mainstream teacher and the English language learners was very limited, particularly for Rita who had a very limited fluency. Her limited fluency was interpreted as a handicap and the teacher expected her to acquire fluency in the language before any form of interaction. The interaction between Rita and Mrs. Banks was only established when she came back the following academic year more fluent in English. The teacher hence, provided her with limited opportunities to acquire fluency with comprehensible input. Comprehensible input was, however, provided to Nadine, Rita2 through their interaction with their mainstream teachers and the classroom material. They were more fluent in English and were viewed by their teachers as more suitable for learning.

Crawford (2005) points out different strategies to promote reading comprehension, including pre-reading, guided reading and post reading strategies. Pre-reading strategies, for instance, involve consideration background knowledge of the text, group discussion, and vocabulary development. Looking back at the data, reading was a very common activity in the classrooms. However, the reading activities given to Rita were often not guided and hence would likely not promote literacy development.

Besides, Barrera (1998) argues that reading acquired in context through comprehension and is not conditioned by the level of fluency. In other words, English language learners are able to read and comprehend a text despite their level of fluency. In the case of my student participants however, they were discriminated against on the basis of their language fluency. Rita2 and Nadine were only exposed to content knowledge because of their language fluency while Rita who was not yet fluent was excluded. The same argument goes for the unguided reading activities given to Rita or the lack of interaction between her and her mainstream teacher. Until she developed fluency, she was viewed as incapable and unable to comprehend content knowledge. Such discrimination weighs heavily on the students' self-esteem creating a hurdle to the development of their literacy skills.

Another hindrance to the literacy development of immigrant children is the lack of collaboration between mainstream teachers and ESL teachers. When the students are placed in mainstream classroom as it was the case for my participants, they are pulled out at least once a day for ESL classes which were expected to help students develop the necessary literacy skills to keep up with their mainstream classroom content. However, as I discussed in the findings, there is often no collaboration between both teachers. The lack of collaboration between them hurts participation in classroom activities, posits them as inferior to their peers, and affects their affective filter (Krashen, 2005). Affective filter, according to Krashen relates to the "role of 'affect,' that is, the effect of personality, motivation, and other 'affective variables' on second language acquisition" (p. 43)

On the other hand, although the teachers did not know much about the students' first language, the two learners were allowed to use their languages in the school setting. In allowing the students' first languages, the teachers created instances that valued what they had to bring to the classroom and empowered them. They allowed the students to continue to use their first and native language while acquiring the target one (Lucas et al., 2008). Mrs. Banks, for instance, worked in favor of an interaction between Nadine and Rita as she created collaboration between the two girls (Buendia et al., 2003). 
In addition, welcoming the first language in the school setting eased Rita's task in transferring the knowledge acquired in French to English. As Barrera (1983) argued, "bilingual children do not appear to approach reading, or learning to read, in Spanish and in English as separate, distinct processes" (p. 170). Similarly, Rita's English literacy was influenced by her knowledge of the French language. In the spelling activities in mainstream classroom, she did not get the words right, but she used cognates between French and English to write her spelling words (Templeton, 2009). Her misspelling of the words "mirror[s] minimal phonetic contrasts between [her] primary language and English" (Bear \& Smith, 2009, p. 102).

\section{Implications of This Study and Recommendations}

One of the implications of this study is related to the connection between ESL and mainstream classrooms. As the findings suggest, the students had an inconsistent exposure to content knowledge. That inconsistency was in part due to ESL pull out that took place in the middle of content knowledge and the almost exclusive focus of ESL on basic communication skills (writing, reading, speaking, and listening). It is essential that mainstream and ESL teachers establish a collaborative relationship between the two instructional spaces and create a more positive learning environment for immigrant students. Besides, it is also essential for ESL teachers to include subject matter knowledge in their literacy instructions.

Mainstream teachers need to be equipped with knowledge of second language literacy development. An awareness of second language literacy would provide them with the necessary tools to address the linguistic challenges of their immigrant student populations. For instance, it would allow them to view students' first language as an asset and use it for an effective development of literacy in English. Also, an awareness of the role of L1 in L2 learning process would allow teachers to develop strategies to include ELLs in instruction, even when the latter have not yet developed the English fluency skills deemed necessary for instruction.

\section{References}

Barrera, R. (1983). Bilingual reading in the primary grades: Some questions about questionable views and practices. In T. H. Escobedo (Ed.), Early childhood bilingual education: A Hispanic Perspective (pp. 164-183). New York, NY: Teachers College Press.

Bogdan, R. C., \& Biklen, S. K. (2007). Qualitative research for education: an introduction to theory and methods. Boston, MA: Allyn \& Bacon.

Crawford, A. N. (2005). Communicative approaches to second language acquisition: From oral language development into the core curriculum and L2 literacy. In C. F. Leyba (Ed.), Schooling and language minority students: A theoretico-practical framework (pp. 65-117). Los Angeles, CA: LBD Publishers.

Cummins, J. (2000). Language, power and pedagogy: Bilingual children in the crossfire. Buffalo, NY: Multilingual Matters.

Emerson, R. M., Fretz, R., \& Shaw, L. (1995). Writing ethnographic fieldnotes. Chicago, IL: The University of Chicago Press. http://dx.doi.org/10.7208/chicago/9780226206851.001.0001

Garcia, G. E. (2003). The reading comprehension development and instruction of English language learners. In A. P. Sweet, \& C. E. Snow (Eds.), Rethinking reading comprehension. New York, NY: Guilford.

Goodwin, A. L. (2002). Teacher preparation and the education of immigrant children. Education and Urban Society, 34, 156-172. http://dx.doi.org/10.1177/0013124502034002003

Iddings, A. C. D., Risko, V. J., \& Rampulla, M. P. (2009). When you don't speak their language: Guiding English-language learners through conversation about text. The Reading Teacher, 63, 52-61. http://dx.doi.org/10.1598/RT.63.1.5

Krashen, S. D. (2005). Bilingual education and second language acquisition theory. In C. F. Leyba (Ed.), Schooling and language minority students: A theoretico-practical framework (pp. 33-61). Los Angeles, CA: LBD Publishers.

Ladson-Billings, G. (2002). I ain't writin' nuttin': Permission to fail and demands to succed in urban classrooms. In L. Delpit, \& J. K. Dowdy (Eds.), The skin that we speak (pp. 107-120). New York, NY: The New Press.

Ladson-Billings, G. (2007). Culturally relevant teaching: Theory and practice. In J. A. Banks, \& C. A. Banks (Eds.), Multicultural education: Issues and perspectives (pp. 221-245). New York, NY: John Wiley.

Lucas, T., Villegas, A. M., \& Freedson-Gonzalez, M. (2008). Linguistically responsive teacher education: Preparing classroom teachers to teach English language learners. Journal of Teacher Education, 59, 361-373. http://dx.doi.org/10.1177/0022487108322110 
Patton, M. Q. (1990). Qualitative evaluation and research methods. New York, NY: Sage Publications.

Purcell-Gates, V. (2002). “... As soon as she opened her mouth!” Issues of language, literacy, and power. In L. Delpit, \& J. K. Dowdy (Eds.), The skin that we speak (pp. 49-61). New York, NY: The New Press.

Templeton, S. (2009). Spelling-meaning relationships among languages: Exploring cognates and their possibilities. In L. Helman (Ed.), Literacy development with English language learners: Research-based instruction in grades $k-6$ (pp. 196-212). New York, NY: The Guilford Press.

Verplaetse, S. L., \& Migliacci, N. (2008). Inclusive pedagogy: An introduction. In S. L. Verplaetse, \& N. Migliacci (Eds.), Inclusive pedagogy for English language learners: A handbook of research-informed practices (pp. 3-13). New York, NY: Taylor \& Francis Group.

Villas-Boas, A. (1998). The effects of parental involvement in homework on student achievement in Portugal and Luxembourg. Childhood Education, 74, 367-71. http://dx.doi.org/10.1080/00094056.1998.10521152

Wallace, C. (2008). Vocabulary: Key to teaching English language learners to read. Education Digest: Essential Readings Condensed for Quick Review, 73, 36-39.

\section{Copyrights}

Copyright for this article is retained by the author(s), with first publication rights granted to the journal.

This is an open-access article distributed under the terms and conditions of the Creative Commons Attribution license (http://creativecommons.org/licenses/by/3.0/). 